\title{
Maasai Language
}

National Cancer Institute

\section{Source}

National Cancer Institute. Maasai Language. NCI Thesaurus. Code C154022.

An Eastern Nilotic language spoken in Southern Kenya and Northern Tanzania by the Maasai people. 